\title{
Cytotoxic Activity of 2-O- $\beta$-glucopyranosil Cucurbitacin D from Benalu Batu (Begonia sp.) Growing in Morowali, Central Sulawesi
}

\author{
Muhammad Sulaiman Zubair ${ }^{1, *}$, Walied Mohamed Alarif ${ }^{2}$, Mohamed Ali Ghandourah ${ }^{2}$, Syariful \\ Anam $^{1}$, and Ibrahim Jantan ${ }^{3}$ \\ ${ }^{1}$ Department of Pharmacy, Science Faculty, Tadulako University, Jl. Soekarno Hatta Tondo, Palu 94118, Indonesia \\ ${ }^{2}$ Department of Marine Chemistry, Marine Science Faculty, King Abdul Aziz University, Jeddah 21589, Saudi Arabia \\ ${ }^{3}$ School of Pharmacy, Taylor's University, Lakeside Campus, Jl. Taylors No. 1, Subang Jaya 47500, Selangor, Malaysia
}

*Corresponding author:

tel: $+62-451-486221$

email: sulaiman_zubair80@yahoo.co.id

Received: February 16, 2019

Accepted: June 30, 2019

DOI: $10.22146 /$ ijc. 43626

\begin{abstract}
Benalu batu (Begonia sp.) had been used traditionally as an anticancer medicinal plant by Wana tribe in Morowali, Central Sulawesi, This study aims to evaluate the cytotoxic activity of 2-O- $\beta$-glucopyranosil cucurbitacin $D$, isolated from the ethyl acetate soluble fraction of Benalu batu (Begonia sp.) and to determine its action on apoptosis induction. Benalu batu (Begonia sp.) herb was extracted by maceration using ethanol $96 \%$ as a solvent. Vacuum liquid column chromatography and preparative thin layer chromatography have been applied on fractionation and isolation of the compound. The structure elucidation was performed by extensive analysis of $1 D / 2 D$ nuclear magnetic resonance (NMR) and Mass Spectrophotometer (MS). Cytotoxic activity against human breast adenocarcinoma (MCF-7) and human colon colorectal carcinoma (HCT-116) cell lines were performed by 5-diphenyltetrazolium bromide (MTT) method. Annexin V-FITC assay was employed to determine the apoptosis induction. 2-O- $\beta$-glucopyranosil cucurbitacin $D$ showed potent cytotoxic activity against MCF-7 and HCT-116 with the $I_{50}$ of 19.913 and $0.002 \mu \mathrm{g} / \mathrm{mL}$, respectively. Annexin V-FITC assay clearly exhibited the cytotoxic mechanism on MCF-7 and HCT116 via apoptosis induction with a significant percentage of early and late apoptosis of 75.8 and $78.4 \%$, respectively. This study reveals the potential cytotoxic activity of 2-O$\beta$-glucopyranosil cucurbitacin $D$ isolated from Benalu batu and its mechanism via apoptosis induction.
\end{abstract}

Keywords: Begonia sp.; 2-O- $\beta$-glucopyranosil cucurbitacin D; cytotoxic; MCF-7; HCT-116

\section{- INTRODUCTION}

Medicinal plants were abundant in Indonesia and used by local people to traditionally treat several diseases. Moreover, medicinal plants were also a rich source for discovering new drugs, and after research and development, they can lead to being a potent drug which can be used in clinical practice. More than $60 \%$ of the drugs available in the market were derived from natural source [1-3].

Begoniaceae, a plant family with approximately 1600 species, widely distributed along with subtropical and tropical areas over the world [4]. Our literature survey found that only about 10 species of Begonia plants were studied up to now regarding the chemical composition and biological activity study. Most of the compounds reported from Begonia species are flavonoids, triterpenoids, steroids, and their glycosides along with alkaloid [5]. The biological activity was ranging from antibacterial [6-7], antioxidant [8], antihyperglycemic [9], antiviral to cytotoxic activities [10-12].

Benalu batu (Begonia sp.) was traditionally used as an ethnomedicinal plant by Wana tribe in Morowali, Central Sulawesi, to treat several diseases, such as tumor, 
cancer, asthma, dry cough, lumbago, kidney failure, ulcer, laxatives, waging irregular menstruation, urolithiasis, tuberculosis, diabetes, eczema, and gout. Our previous study has established the anticancer activity of the methanol extract of this herb plant against breast and cervical cancer cell lines (T47D and HeLa cells) [13]. In our interest to investigate the phytochemical anticancer agents from this herb plant, a preliminary in silico docking study to early identify the predictive potential natural product compounds type from Begonia species have been performed. An alkaloid, a steroidal glycoside, flavonoid glycoside, and triterpenoid glycoside were recommended compounds that might have possible action to inhibit the proliferation of cancer cells [5]. This study reports the isolation and structure elucidation of one of the targeted compounds, a terpenoid glycoside, assigned as 2-O- $\beta$ glucopyranosil cucurbitacin D (Fig. 1) from ethyl acetate soluble fraction of Benalu batu (Begonia sp.). To the best of our knowledge, this is the first report of bioactive compound reported from Benalu batu (Begonia sp.), and it confirmed the presence of cucurbitacin type compounds on Begonia species. Cytotoxic activity and apoptosis assay of the isolated compound on several types of cancer cell lines were also evaluated.

\section{- EXPERIMENTAL SECTION}

\section{Materials}

The whole plant (herb) of Benalu batu (Begonia sp.), which grows in the mountain, was collected from Morowali, Central Sulawesi, on April 2014. The plant was still identified by Wisnu H. Ardi (Taxonomist) at Bogor Botanic Garden, Bogor, Indonesia and deposited as a dried specimen (BSP 00020414) at Phytochemistry Laboratory, Department of Pharmacy, Tadulako University.

\section{Instrumentation}

TLC aluminium sheets $20 \times 20 \mathrm{~cm}$ silica gel $60 \mathrm{~F}_{254}$ was used. Silica gel 60 (Merck) for vacuum liquid column chromatography (230-400 mesh) was used. Preparative precoated TLC glass plates SIL G-25 UV $254,0.25 \mathrm{~mm}$ silica gel and Sephadex LH-20 (Sigma, St. Louis, USA) were used for isolation and purification of the compounds. Spots

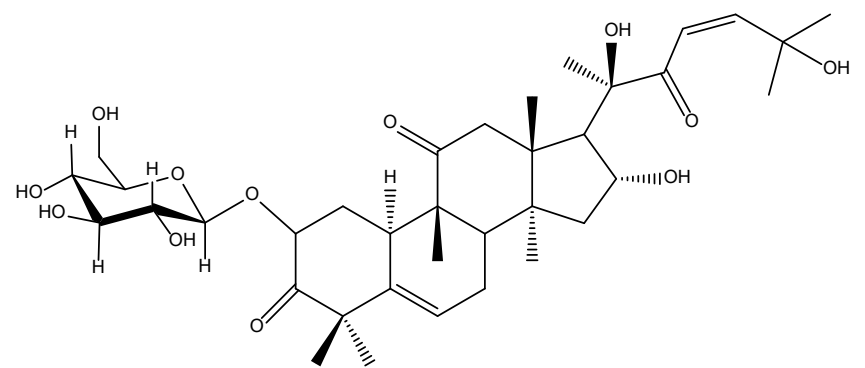

Fig 1. 2-O- $\beta$-glycopyranosil cucurbitacin D

on TLC were visualized by using spraying reagent of methanol-sulphuric acid and $p$-anisaldehyde-sulphuric acid for terpenoid detection. Nuclear magnetic resonance (NMR) were recorded for $1 \mathrm{D}$ and $2 \mathrm{D}$ on Avance ${ }^{\mathrm{III}}$ Bruker WM $600 \mathrm{MHz}$ for ${ }^{1} \mathrm{H}$ and $150 \mathrm{MHz}$ for ${ }^{13} \mathrm{C}$. Chemical shifts are given $\delta$ (ppm) relative to TMS as internal standard, and deuterated chloroform was used as solvents. Electron impact mass spectra were determined at $70 \mathrm{eV}$ using a Kratos GCMS-25 instrument.

\section{Procedure}

\section{Extraction and isolation}

The herb plant was dried in the shade at room temperature. The dried simplicia ( $250 \mathrm{~g})$ was extracted with ethanol $96 \%(3 \times 0.8 \mathrm{~L}, 24 \mathrm{~h}$ for each batch $)$ at room temperature. The solvent was removed in a vacuum until reached a residue $(15 \mathrm{~g})$ referred to as crude ethanol extract. The ethanol extract $(10 \mathrm{~g})$ was suspended in water and successively partitioned with $\mathrm{n}$-hexane and ethyl acetate to obtain $n$-hexane and ethyl acetate soluble fraction. The ethyl acetate fraction (3 g) was chromatographed on silica gel (60-120 mesh), and the packed column was eluted by employing gradient system of the solvent of $n$-hexane $100 \%, n$-hexane/ethyl acetate mixture, followed by ethyl acetate/methanol mixture and methanol $100 \%$. Forty fractions of $50 \mathrm{~mL}$ each were collected. Similar fractions were collected together according to TLC pattern in eight fractions (F1F8). The fourth fraction, which is detected to contain terpenoid, was continued to further isolation using successive TLC preparative with a solvent system of methanol: chloroform (8:2) as a mobile phase. A spot with $\mathrm{R}_{\mathrm{f}} 2.40$ (purple color with $\mathrm{H}_{2} \mathrm{SO}_{4} / \mathrm{MeOH}$ ) was taken to give the compound $(5.6 \mathrm{mg}$ ). 


\section{Compound}

Identification of 2-O- $\beta$-glucopyranosil cucurbitacin $\mathrm{D}$ was determined by using the spectroscopic method on MS, 1D/2D NMR and comparison with the literature. The chemical structure of isolated compounds can be seen in Fig. 1.

\section{2-O-B-glucopyranosil cucurbitacin D. Gummy} material, HRESIMS (positive-ion mode), $\mathrm{m} / \mathrm{z}=679.8068$ $[\mathrm{M}+\mathrm{H}]^{+}$(Calc. for $\left.\mathrm{C}_{36} \mathrm{H}_{55} \mathrm{O}_{12}, 679.3610\right)$.

${ }^{1} \mathrm{H} \mathrm{NMR}\left(600 \mathrm{MHz}, \mathrm{CDCl}_{3}\right): \delta \mathrm{H} 7.088(1 \mathrm{H}, \mathrm{d}(10.8)$, H-24), 6.806 (1H, d (10.8), H-23), 5.716 (1H, br s, H-6), $4.834(1 \mathrm{H}, \mathrm{br}$ s, H-2), 4.431 (1H, br s, H-1'), 4.256 (s, OH20), 3.941 (2H, m, H-6'), 3.936 (d (3.0), OH-16), 3.780 (1H, m, H-16), 3.650 (1H, m, H-5'), 3.569 (1H, m, H-4'), 3.548 (s, OH-25), 3.488 (1H, m, H-3'), $3.417(1 \mathrm{H}, \mathrm{m}, \mathrm{H}-$ 2'), 3.337 (1H, d (9), Ha-12), 2.902 (1H, br d (7.2), H-10), 2.668 (1H, d (9), Hb-12), 2.367 (1H, d (8.4), H-17), 2.353 (1H, m, Ha-1), 2.315 (1H, d(4.8), Hb-7), 1.997 (1H, m, H8), 1.993 (1H, d(4.8), Ha-7), 1.957 (1H, m, H-15a), 1.626 (1H, m, H-15b), $1.450(1 \mathrm{H}, \mathrm{m}, \mathrm{Hb}-1), 1.384(3 \mathrm{H}, \mathrm{s}, \mathrm{H}-21)$, 1.357 (3H, s, H-28), 1.259 (3H, s, H-27), 1.236 (3H, s, H29), $1.227(3 \mathrm{H}, \mathrm{s}, \mathrm{H}-26), 1.127(3 \mathrm{H}, \mathrm{s}, \mathrm{H}-30), 1.011(3 \mathrm{H}, \mathrm{s}$, $\mathrm{H}-19), 0.951$ (3H, s, H-18).

${ }^{13} \mathrm{C}$ NMR $\left(150 \mathrm{MHz}, \mathrm{CDCl}_{3}\right): \delta \mathrm{C} 216.452(\mathrm{C}-11)$, 212.155 (C-3), 202.591 (C-22), 156.748 (C-24), 140.222 (C-5), 119.944 (C-6), 118.218 (C-23), 102.969 (C-1'), 79.600 (C-2), 78.901 (C-20), 77.204 (C-16), 76.425 (C-5'), 76.257 (C-3'), 73.839 (C-2'), 71.271 (C-25), 70.255 (C-4'), 61.988 (C-6'), 50.815 (C-4), 50.612 (C-14), 50.335 (C-9), 48.820 (C-12), 48.390 (C-17), 47.824 (C-13), 42.374 (C-8), 34.770 (C-1), 34.581 (C-15), 33.917 (C-10), 29.686 (C-28), 29.234 (C-27), 28.069 (C-26), 24.034 (C-21), 22.679 (C-7), 21.310 (C-29), 19.656 (C-18), 19.183 (C-19), 18.148 (C-30).

\section{Cytotoxic activity}

The cytotoxic activity was performed by MTT colorimetric assay as described in our previous study [14]. About $1.0 \mathrm{mg}$ of compound were dissolved by $1.0 \mathrm{~mL}$ of RPMI-1640 medium to obtain stock solutions of $1000 \mu \mathrm{g} / \mathrm{mL}$. Then, the sample was diluted to desired concentrations of $6.25,12.5,25$, and $50 \mu \mathrm{g} / \mathrm{mL}$ using dimethylsulphoxide (DMSO) in which the DMSO concentration in each sample was $1 \% \mathrm{v} / \mathrm{v}$. The cancer cells of human breast adenocarcinoma (MCF-7) and human colon colorectal carcinoma (HCT-116) were batch cultured for $10 \mathrm{~d}$, then seeded in 96 well plates of $1 \times 10^{4}$ cells/well in fresh complete growth medium in 96-well flat bottom culture plates at $37^{\circ} \mathrm{C}$ using incubator in $5 \%$ $\mathrm{CO}_{2}$ humidified atmosfer (CelCulture, Esco Medical ApS, Denmark). After $24 \mathrm{~h}$ incubation, the medium (without serum) was added and cells were incubated for $48 \mathrm{~h}$ either alone (negative control) or with different concentrations of the sample. Then, the cells were added with $10 \mu \mathrm{L} /$ well of MTT $(5 \mathrm{mg} / \mathrm{mL})$ and incubated again for $4 \mathrm{~h}$ in an incubator at $37^{\circ} \mathrm{C}$ in $5 \% \mathrm{CO}_{2}$ humidified atmosphere. The reaction was stopped by adding $100 \mu \mathrm{L}$ dimethylsulfoxide (DMSO) and the plate was then placed for $15 \mathrm{~min}$ in the shade room. The absorbance of each well was read at $550 \mathrm{~nm}$ wavelength in Elisa Reader (Infinite M200 pro NanoQuant, Tecan, Switzerland), using wells without cells as blanks. All experiments were performed in triplicate. Anticancer drugs of doxorubicin and fluorouracil were used as a positive standard. The effect of compounds on the proliferation of cancer cells was expressed as the $\%$ cytoviability, using the following formula:

$\%$ Cytoviability $=\frac{\text { Absorbance of treated cells }}{\text { Absorbance of control cells }} \times 100 \%$

The probit analysis on SPSS 17.0 (SPSS Inc., Chicago IL, USA) was used to calculate the $\mathrm{IC}_{50}$ by plotting the series of concentration and the percentage of cytoviability.

\section{Annexin V-FITC apoptosis assay}

Briefly, $1 \times 10^{5}$ of cells lines (MCF-7 and HCT-116) were treated with $5.0 \mu \mathrm{L}$ annexin V-FITC and $5.0 \mu \mathrm{L}$ propidium iodide (PI) using the apoptosis detection kit (BD Biosciences, San Jose, CA) according to the manufacturer's protocol. Flow cytometry on FACScanto II (BD Biosciences, San Jose, CA) was used to analyze the binding of Annexin V-FITC and PI without gating restrictions using 10,000 cells. Logarithmic amplification of both the FL1 (FITC-A) and the FL2 (PIA) channels were performed to obtain the data. CellQuest software was used for analysis the quadrant of coordinate dot plots. The photomultiplier voltage and compensation setting adjustment to eliminate the 
spectral overlap between the FL1 and the FL2 signals was done by using the unstained cells.

\section{- RESULTS AND DISCUSSION}

\section{Cytotoxic Activity}

The result of the cytotoxic activity of $2-\mathrm{O}-\beta-$ glucopyranosil cucurbitacin D can be seen in Fig. 2. It is clearly showed that 2-O- $\beta$-glucopyranosil cucurbitacin D has ability to inhibit the proliferation of both MCF-7 and HCT-116 cell lines. However, the inhibition on HCT-116 was higher than on MCF-7, where at the concentration of $25 \mu \mathrm{g} / \mathrm{mL}$, the percentage of cell viability on HCT-116 was $6.88 \%$ compared to MCF-7 (48.26\%). Therefore, the $\mathrm{IC}_{50}$ of 2-O- $\beta$-glucopyranosil cucurbitacin D on HCT-116 was also higher than on MCF-7 with the value of 0.002 and $19.913 \mu \mathrm{g} / \mathrm{mL}$, respectively (Table 1 ).

\section{Annexin V-FTIC Apoptosis Assay}

The result of annexin V-FTIC of 2-O- $\beta$ glucopyranosil cucurbitacin $\mathrm{D}$ can be seen in Fig. 3. It clearly showed that the significant percentage of early and late apoptosis of 2-O- $\beta$-glucopyranosil cucurbitacin D on HCT-116 and MCF-7 was 78.4 and $75.8 \%$, respectively.

Compound 2-O- $\beta$-glucopyranosil cucurbitacin D was isolated as a gummy material. Liebermann-Burchard test supported that the compound is a terpenoid. Moreover, it gave a reddish spot on a TLC plate after spraying with $p$-anisaldehyde as well. The analysis of HRESI-MS at $\mathrm{m} / \mathrm{z} 679.3610[\mathrm{M}+\mathrm{H}]^{+}$supporting the molecular structure of glycosidal triterpenoid with the molecular formula of $\mathrm{C}_{36} \mathrm{H}_{54} \mathrm{O}_{12}$ that can be suggested to have 10 degrees of unsaturation. The ${ }^{13} \mathrm{C}$ NMR spectral data exhibited 36 signals of a carbon atom which is categorized by DEPT into eight methyls, six methylene, twelve methines, and ten quaternary carbons. The presence of glycopyranosil moiety was supported by the resonance of an anomeric carbon at $102.969 \mathrm{ppm}$, together with four methines at 76.425, 76.257, 73.839, $70.255 \mathrm{ppm}$ and one methylene carbon at $61.988 \mathrm{ppm}$. Three carbonyl carbons observed at 216.452, 212.155, and $202.591 \mathrm{ppm}$ supporting the skeleton of cucurbitacin triterpenoid skeleton attached by single monosaccharide moiety. The carbonyl group was assigned to C2, C11, and C22, respectively. Moreover, four olefinic carbon signals $(118.218,119.944,140.222$ and 156.748) supported the main skeleton of cucurbitacin type triterpenoid by suggesting the presence of trisubstituted double bond at C5-C6 and a disubstituted double bond at C23-C24.

The ${ }^{1} \mathrm{H}$ NMR revealed the skeleton of cucurbitacin type triterpenoid in the form of a glycosidic compound, proven by the presence of eight methyl singlet signal in the area between $0.951-1.384 \mathrm{ppm}$, the vicinal coupling of $\mathrm{AB}$ system between $\mathrm{H}-23$, resonating at 6.806 , and $\mathrm{H}-24$

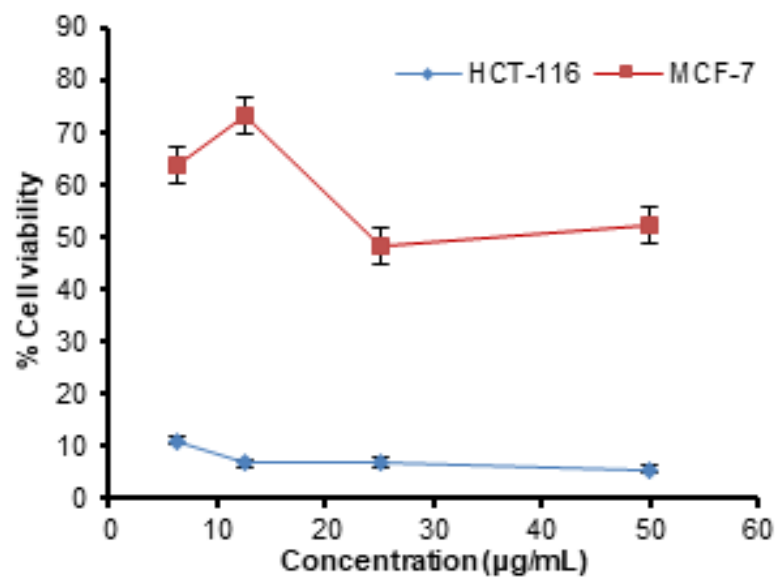

Fig 2. The percentage of cell viability of 2-O- $\beta$ glucopyranosil cucurbitacin D on MCF-7 and HCT-116

Table 1. Cytotoxic activity of 2-O- $\beta$-glucopyranosil cucurbitacin D

\begin{tabular}{lcc}
\hline Compound & \multicolumn{2}{c}{$\mathrm{IC}_{50}(\mu \mathrm{g} / \mathrm{mL})$} \\
\cline { 2 - 3 } & $\mathrm{MCF}-7$ & $\mathrm{HCT}-116$ \\
\hline 2-O- $\beta$-glucopyranosil cucurbitacin D & $19.2 \pm 5.094$ & $0.002 \pm 0.019$ \\
Doxorubicin $^{\mathrm{a}}$ & $0.02 \pm 0.038$ & - \\
Fluorouracil $^{\mathrm{b}}$ & - & $21.7 \pm 4.019$
\end{tabular}

${ }^{\mathrm{a}}$ Doxorubicin was used as a positive control on MCF-7, ${ }^{\text {bFluorouracil was used as a }}$ positive control on HCT-116, Data are presented as mean \pm standard deviation, SD 

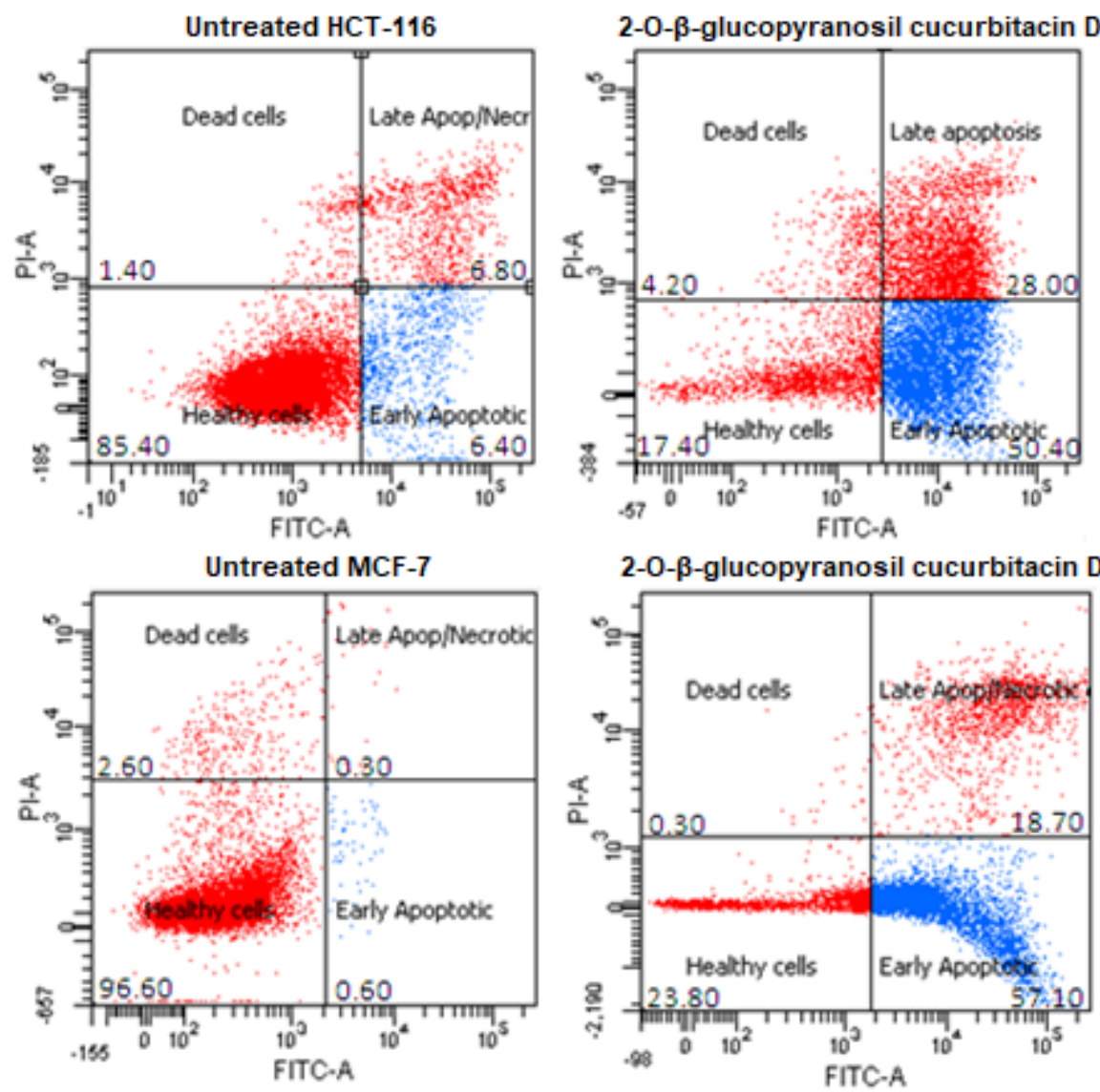

Fig 3. Effect of 2-O- $\beta$-glucopyranosil cucurbitacin D on HCT-116 and MCF-7 on annexin V-FITC-positive staining. The four quadrants identified as LL (healthy cells); LR (early apoptotic); UR (late apoptotic) and UL (necrotic)

at 7.088, where its $\mathrm{J}$ value of 10.8 , suggesting the stereochemistry for C-23-24 is Z configuration [15]. A broad singlet proton signal at 5.716, assigned for C6. A typical triplet signal at 3.780 for $\mathrm{H}-16$, a characteristic of geminal coupling of $\mathrm{H}-12$ as two duplets at 2.668 and $3.337(\mathrm{~J}=9 \mathrm{~Hz})$, an upfield shift at 4.834 for $\mathrm{H}-2$, which are attributed by the glycosidic linkage of this position and also from carbonyl group at C-3. A single monosaccharide moiety was revealed by an anomeric proton at 4.431, together with five signals of oxygenated carbon in the range of 3.417-3.941.

Cucurbitacin type triterpenoid was mostly encountered in the cucurbitaceae family plant. However, the presence of this compound was also reported from the genus of Begoniaceae. Among the begoniaceae plants, only Begonia heracliofera and Begonia nantoensis were reported to contain cucurbitacin type compounds [1112]. Therefore, this compound, 2-O-B-glycopyranosil cucurbitacin D, found for the first time in Benalu batu (Begonia sp.), can be a marker compound for the species of Begonia.

The cytotoxic activity of cucurbitacin type compounds was intensively studied. Cucurbitacin B, cucurbitacin $\mathrm{E}$, and cucurbitacin I have been reported to inhibit the cell proliferation of human breast cancer [1618]. Cucurbitacin B, cucurbitacin D, and dihydrocucurbitacin $\mathrm{D}$ inhibited the growth of human nasopharyngeal carcinoma $(\mathrm{KB})$ cells, murine embryonic fibroblasts (313) cells, human prostate carcinoma (PC-3) cells, murine methylcholanthreneinduced fibrosarcoma (MethA) cells [11]. Cucurbitacin $B$ and dihydrocucurbitacin $B$ inhibited the cell proliferation of mouse embryonic fibroblast (NIH3T3) and virally transformed form (KA3IT) [19]. In the form of glycoside, cucurbitacin I glycoside and cucurbitacin E glycoside has been reported to inhibit Hepatoma Cell 
Line (HepG2) and mice-bearing tumor of Ehrlich's ascites carcinoma (EAC) [20]. This fact showed the potential anticancer activity for this type of compounds.

2-O- $\beta$-glycopyranosil cucurbitacin D exhibited potent cytotoxic activity against MCF-7 and HCT-116 cancer cell lines with the $\mathrm{IC}_{50}$ of 19.913 and $0.002 \mu \mathrm{g} / \mathrm{mL}$, respectively. This result encourages us to further study its mechanism on apoptosis induction. Both cell lines were stained by annexin A and gave a proper indication on early and late apoptosis, as shown in Fig. 3. The result showed that there is a significant increase in the percentage of annexin V-FITC-positive apoptotic cells (early + late apoptotic) on HCT-116 and MCF-7 when compared to the untreated cells (Fig. 4). Therefore, it can be concluded that 2-O- $\beta$-glycopyranosil cucurbitacin $\mathrm{D}$ inhibited the cell proliferation of HCT-116 and MCF-7 via apoptosis induction. Some studies had reported cucurbitacin type compounds could induce apoptosis mechanism, such as cucurbitacin D exhibit anticancer activity in human breast cancer by inhibiting Stat 3 and Akt signaling and cucurbitacin B induces apoptosis by inhibition of the JAK/STAT pathway [21-22]. Therefore, 2-O- $\beta$-glycopyranosil cucurbitacin D might also induce apoptosis in this same mechanism.

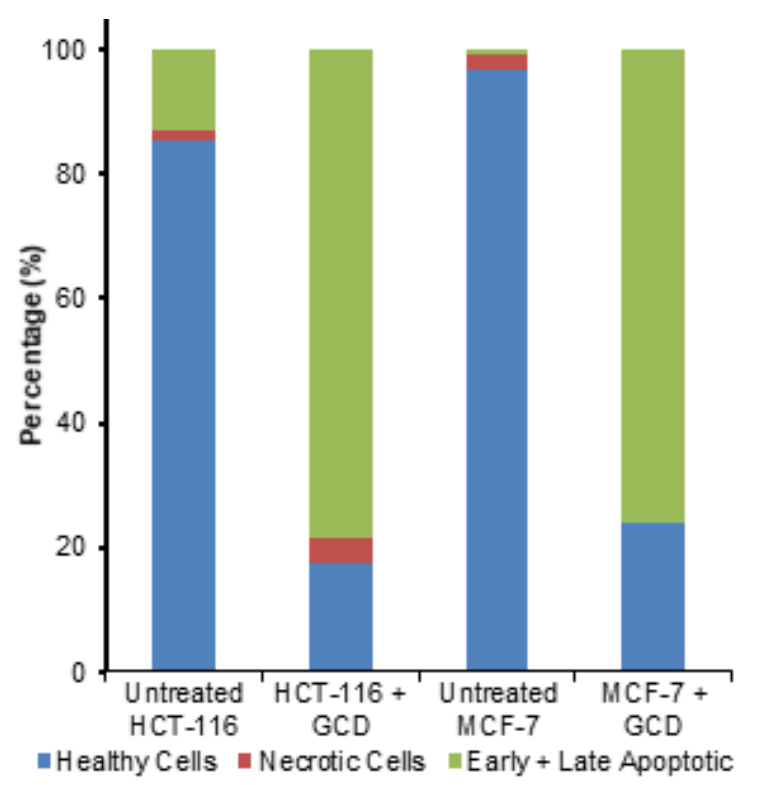

Fig 4 . The percentage of healthy cells, necrotic cells and early + late apoptotic cells on HCT-116 and MCF-7 cell lines after exposed by2-O- $\beta$-glucopyranosil cucurbitacin D (GCD)

\section{- CONCLUSION}

2-O- $\beta$-glycopyranosil cucurbitacin $D$ was successfully isolated for the first time from Benalu batu (Begonia sp.). This result indicated that the presence of cucurbitacin type triterpenoid could be a marker compound for Begonia plant species. It exhibited potent cytotoxic activity against HCT-116 and MCF-7 as well via apoptosis induction.

\section{- ACKNOWLEDGMENTS}

The author acknowledges the Ministry of Research, Technology and Higher Education, Republic of Indonesia, for supporting this study through a grant of INSINAS 2015 (RD-2015-0106).

\section{- REFERENCES}

[1] Harvey, A.L., Eldrada-Ebel, R., and Quinn, R.J., 2015, The re-emergence of natural products for drug discovery in the genomics era, Nat. Rev. Drug Discovery, 14 (2), 111-129.

[2] Dias, D.A., Urban, S., and Roessner, U.A., 2012, Historical overview of natural products in drug discovery, Metabolites, 2 (2), 303-333.

[3] Newman, D.J., and Cragg, G.M., 2012, Natural product as sources of new drugs over the 30 years from 1981 to 2010, J. Nat. Prod., 75 (3), 311-335.

[4] Ding, B., Nakamura, K., Kono, Y., Ho, M.J., and Peng, C.I., 2014, Begonia jinyunensis (Begoniaceae, section Platycentrum), a new palmately compound leaved species from Chongqing, China, Bot. Stud., 55,62 .

[5] Zubair, M.S., Anam, S., Khumaidi, A., Susanto, Y., Hidayat, M., and Ridhay, A., 2016, Molecular docking approach to identify potential anticancer compound from Benalu batu (Begonia sp.), AIP Conf. Proc., 1755 (1), 080005.

[6] Ramesh, N., Viswanathan, M.B., Saraswathy, A., Balakrishna, K., Brindha, P., and Lakshmanaperu malsamy, P., 2002, Phytochemical and antimicrobial studies of Begonia malabarica, J. Ethnopharmacol., 79 (1), 129-132.

[7] Jeeva, S., and Antonisamy, J.M., 2012, Antibacterial and phytochemical studies on methanolic 
extracts of Begonia floccifera Bedd. flower, Asian Pac. J. Trop. Biomed., 2 (1), S151-S154.

[8] Kalpanadevi, V., and Mohan, V.R., 2012, In vitro antioxidant studies of Begonia malabarica Lam. and Begonia floccifera Bedd, Asian Pac. J. Trop. Biomed., 2 (3), S1572-1577.

[9] Pandikumar, P., Babu, N.P., and Ignacimuthu, S., 2009, Hypoglycemic and antihyperglycemic effect of Begonia malabarica Lam. in normal and streptozotocin induced diabetic rats, $J$. Ethnopharmacol., 124 (1), 111-115.

[10] Doskotch, R.W., and Hufford, C.D., 1970, Hexanorcucurbitacin D, a degraded cucurbitacin from Begonia tuberhybrida var. alba, Can. J. Chem., 48, 1787-1788.

[11] Frei, B., Heinrich, M., Herrmann, D., Orjala, J.E., Schmitt, J., and Sticher, O., 1998, Phytochemical and biological investigation of Begonia heracleifolia, Planta Med., 64 (4), 385-386.

[12] Wu, P.L., Lin, F.W., Wu, T.S., Kuoh, C.S., Lee, K.H., and Lee, S.J., 2004, Cytotoxic and anti-HIV principles from the rhizomes of Begonia nantoensis, Chem. Pharm. Bull., 52 (3), 345-349.

[13] Anam, S., Yuliet, Ritna, A., Dwimurti, F., Rismayanti, D., and Zubair, M.S., 2014, Aktivitas sitotoksik ekstrak metanol Benalu batu (Begonia sp.): Ethnomedicine suku Wana Sulawesi Tengah, Indones. J. Pharm. Sci., 12 (1), 10-16.

[14] Zubair, M.S., Anam, S., and Lallo, S., 2016, Cytotoxic activity and phytochemical standardization of Lunasia amara Blanco wood extract, Asian Pac. J. Trop. Biomed., 6 (11), 962-966.

[15] Theodore, C.M., Lorig-Roach, N., Still, P.C., Johnson, T.A., Draskovic, M., Schwochert, J.A., Naphen, C.N., Crews, M.S., Barker, S.A., Valeriote, F.A., Lokey, R.S., and Crews, P., 2015, Biosynthetic products from a nearshore-derived gram negative bacterium enable reassessment of the kailuin depsipeptides, J. Nat. Prod., 78 (3), 441-452.

[16] Duangmano, S., Sae-Lim, P., Suksamrarn, A.,
Domann, F.E., and Patmasiriwat, P., 2012, Cucurbitacin B inhibits human breast cancer cell proliferation through disruption of microtubule polymerization and nucleophosmin/B23 trans location, BMC Complement. Altern. Med., 12, 185.

[17] Lopez-Haber, C., and Kazanietz, M.G., 2013, Cucurbitacin I inhibits Racl activation in breast cancer cells by a reactive oxygen species-mediated mechanism and independently of Janus tyrosine kinase 2 and P-Rex1, Mol. Pharmacol., 83 (5), 11411154.

[18] Kong, Y., Chen, J., Zhou, Z., Xia, H., Qiu, M.H., and Chen, C., 2014, Cucurbitacin E induces cell cycle G2/M phase arrest and apoptosis in triple negative breast cancer, PLoS One, 9 (7), e103760.

[19] Ayyad, S.E.N., Abdel-Lateff, A., Basaif, S.A., and Shier, T., 2011, Cucurbitacins-type triterpene with potent activity on mouse embryonic fibroblast from Cucumis prophetarum, cucurbitaceae, Pharmacogn. Res., 3 (3), 189-193.

[20] Ayyad, S.E.N., Abdel-Lateff, A., Alarif, W.M., Patacchioli, F.R., Badria, F.A., and Ezmirly, S.T., 2012, In vitro and in vivo study of cucurbitacins-type triterpene glucoside from Citrullus colocynthis growing in Saudi Arabia against hepatocellular carcinoma, Environ. Toxicol. Pharmacol., 33 (2), 245-251.

[21] Ku, J.M., Hong, S.H., Kim, H.I., Lim, Y.S., Lee, S.J., Kim, M., Seo, H.S., Shin, Y.C., and Ko, SG., 2018, Cucurbitacin D exhibits its anti-cancer effect in human breast cancer cells by inhibiting Stat 3 and Akt signaling, Eur. J. Inflammation, 16, 1-9.

[22] Thoennissen, N.H., Iwanski, G.B., Doan, N.B., Okamoto, R., Lin, P., Abbasi, S., Song, J.H., Yin, D., Toh, M., Xie, W.D., Said, J.W., and Koeffler, H.P., 2009, Cucurbitacin B induces apoptosis by inhibition of the JAK/STAT pathway and potentiates antiproliferative effects of gemcitabine on pancreatic cancer cells, Cancer Res., 69 (14), 5876-5884. 